\title{
KOMPIUTERIZUOTA DINAMOGRAFINĖ SISTEMA PLAUKIKŲ SPECIALIOSIOS JËGOS PARAMETRAMS TIRTI
}

\author{
Ilona Judita Zuozienè ${ }^{1}$, Algimantas Kriščiukaitis², Kazimieras Muckus ${ }^{1}$ \\ Lietuvos kūno kultūros akademijal', Kauno medicinos universiteto Biomedicininiu tyrimu institutas², \\ Kaunas, Lietuva
}

Ilona Judita Zuozienė. Docentė socialinių mokslų daktarè. Lietuvos kūno kultūros akademijos Vandens sporto šakų katedros docentė. Mokslinių tyrimų kryptis — sportuojančiujų fizinio parengtumo kontrolè ir treniruotès valdymas.

\begin{abstract}
SANTRAUKA
Tyrimo tikslas - ištirti ir ìvertinti plaukiku specialiosios jègos dinaminiu parametru tyrimo galimybes taikant originaliq kompiuterizuota dinamografinę sistemq. Tiriamieji ir tyrimo metodika: 24 j̇vairaus meistriškumo plaukikai atliko standartinius testus (Оноприенко, Атаманов, 1973; Yeater et al., 1981; Фомиченко, 2001), kuriu теtи bиvo registruojami traukio jégos parametrai: a) maksimalioji traukio jèga sausumoje imituojant plaukimo peteliške grybšni izometriniu režimu ( $F$ max s) ir su pririšstu guminiu amortizatoriumi plaukiant vandenyje; $b$ ) vien rankomis ( $F$ vr); c) vien kojomis ( $F v k)$; d) visiškai koordinuojant ranku ir kojujudesius (F vpk); e) traukio jèga 30-ies sekundžiu trukmes plaukimo testo metu (maksimalioji traukio jèga F max 30 ir traukio jèga 30-a sekundę $F 30$ s). Traukio jegos kitimas buvo registruojamas ir analizuojamas originalia kompiuterizuota dinamografine sistema. Ja sudaro dinamometras, kurio elektrinis signalas, proporcingas traukio jègai, buvo registruojamas specialios konstrukcijos elektroniniu signalo kaupikliu. Signalas, užregistruotas duomenu ìvedimo i̇renginiu „,Data Acquisition Card DAS1402" (Cyber Research, USA), buvo skaitmenizuojamas ir talpinamas personalinio kompiuterio atmintyje. Diskretizavimo dažnis buvo $1000 \mathrm{~Hz}$, o signalo skiriamoji geba - 12 bitu, arba 4096 lygiai. Traukio jëgos signalo parametru analize atlikta specialia programa, sukurta naudojant programavimo kalba DELPHI. Visi registruoti traukio jégos rodikliai buvo lyginami su $100 \mathrm{~m}$ nuotolio plaukimo laisvuoju stiliumi maksimaliais rezultatais.

Remiantis tyrimu duomenimis, daromos šios išvados: 1) plaukiku specialiosios jégos registravimas ir analize naudojant kompiuterizuota dinamografine sistema leidžia fiksuoti ne tik absoliučius traukio jègos dydžius, bet ir sukuriamus traukio jègos svyravimu netolygumus plaukimo ciklo ir net grybšnio metu, kurie teikia svarbia informacija apie sportininko techninio parengtumo lygi; 2) tiriant plaukiku specialuji fizini parengtuma kompiuterizuota dinamografine sistema nustatyta, kad plaukiku testavimo metu dažnai naudojamas maksimaliosios traukio jègos sausumoje rodiklis $100 \mathrm{~m}$ plaukimo laisvuoju stiliumi rezultatams prognozuoti pasirodè nepakankamai tinkamas. Geriausiai rezultatus rodo šie plaukimo su pririštu amortizatoriumi testo traukio jegos rodikliai: traukio jèga plaukiant visiška koordinacija (F vpk), maksimalioji 30 sekundžiu testo jëga (F max 30), jèga 30-q sekundę (F 30 s).
\end{abstract}

Raktažodžiai: plaukimas, traukio jèga, dinamografinè sistema.

\section{IVADAS}

$\mathrm{P}$ laukiku specialusis parengtumas bei techninių igūdžių tobulinimas aktualus visais sportininkų rengimo etapais ir glaudžiai siejasi su jègos lavinimu. Yra nustatyta, kad specialiosios jègos išlavejjimo lygis gana reikšmingai veikia plaukiku rezultatus. Tačiau netinkamas jègos ypatybiu lavinimas gali sukelti neigiamą efektą (Counsilmen, J. E., Counsilmen, В. Е., 1994; Гордон, Сируц, 1990; Фомиченко, 2001). Todèl plaukiku jègos lavinimas bei su šia ypatybe glaudžiai susijęs techninis sportininku tobulejimas nepraranda savo aktualumo ir vis dar žadina mokslininkų, praktikų ieškojimus. Gausu užsienio (Bulgakova et al., 1990; Costill et al.,
1994; Гордон, Сируц, 1990; Фомиченко, 2001; Платонов, 2000 ir kt.) ir Lietuvos (Рудокене, 1981; Скирюс, 1986; Lagūnavičienè, Skyrienè, 1989; Juozaitis ir kt., 1998; Sokolovas ir kt., 1999; Skyrius ir kt., 2004) mokslininkų atliktų darbų, kurių objektas - ivvairaus amžiaus ir meistriškumo plaukiku jègos lavinimo ypatumai.

Vienas iš pagrindinių kiekybinių rodikliu, rodančių plaukikų specialiosios jègos lygi, yra traukio jèga - tai plaukiko judesiais sukuriama varomoji jèga vandenyje. Dažniausiai dèl ribotu techniniu galimybių plaukikų rankų ir kojų raumenų jègos parametrai registruojami atliekant imitacinius pratimus sausumoje (Curran, 1980; 
Фомиченко, 2001; Платонов, 2000 ir kt.). Tас̌iau plaukimo judesių imitacija ant treniruoklių sausumoje pagal dinamines ir laiko charakteristikas bei koordinaciją nevisiškai atitinka plaukikų atliekamus grybšnių judesius specifinèmis sąlygomis (Иссурин, 1988; Bing, 1989; Ратов, 1994 ir kt.).

Ivertinti traukio jègą plaukiant méginama tiesioginiais ir netiesioginiais metodais: matuojama spaudimo jèga ị delno paviršiuc, nardinant rankos modeli i vandens srovę įvairiais kampais, atliekant biomechaninę plaukiko judesių analizę (Satkunskienè, Lagūnavičienè, 2000). Plaukimo praktikoje taip pat naudojami îvairūs dinamometrai, kuriais fiksuojamos maksimalios plaukikuz pastangos atliekant pratimus sausumoje ir plaukiant (Абсалямов, Тимакова, 1983; Hopper et al., 1983; Ikuta et al., 1996 ir kt.), siūloma registruoti informaciją apie išugdomos jègos dinaminių ir kinematinių parametrų pokyčius per laiko vienetą (Dopsaj et al., 2000). Mūsų šalyje vis dar nèra pakankamai patikimų ir tikslių metodų, kurie leistų ne tik registruoti maksimalias traukio jègos reikšmes plaukiant, bet ir fiksuoti jos pokyčius per laiko vienetą. Todèl buvo sukurta kompiuterinè dinamografinè sistema, skirta specialiosios traukio jègos vandenyje parametrams tirti. Ši sistema sukurta bendradarbiaujant Lietuvos kūno kultūros akademijos ir Kauno medicinos universiteto Biomedicininių tyrimų instituto mokslininkams.

Tyrimo tikslas - ištirti ir įvertinti plaukiku specialiosios jègos dinaminiu parametru tyrimo galimybes taikant originalią kompiuterizuotą dinamografinę sistemą.

\section{TYRIMO METODAI IR ORGANIZAVIMAS}

Tiriamieji. Tirtis savanoriškai sutiko 24 įvairaus meistriškumo plaukikai. Jų amžius $19,3 \pm 0,4$ metai, kūno mase $-76,9 \pm 3,2 \mathrm{~kg}$.

\section{Metodai:}

1. Dinamometrija. Plaukikai atliko standartinius testus (Оноприенко, Атаманов, 1973; Yeater et al., 1981; Фомиченко, 2001), kurių metu buvo registruojami traukio jègos parametrai: a) maksimalioji traukio jèga sausumoje imituojant plaukimo peteliške grybšni izometriniu režimu (F max s) ir su pririštu guminiu amortizatoriumi plaukiant vandenyje; b) vien rankomis (F vr); c) vien kojomis (F vk); d) visiškai koordinuojant rankų ir koju judesius (F vpk); e) 30-ies sekundžiu trukmès plaukimo testo metu (maksimalioji traukio jèga F max 30 ir traukio jèga 30 -ą sekundę F $30 \mathrm{~s}$ ). Traukio jègos kitimas buvo registruojamas ir analizuojamas originalia kompiuterizuota dinamografine sistema. Dinamografinę sistemą sudaro dinamometras Np120 (TPG, Ivanovo, USSR), kurio elektrinis signalas, proporcingas traukio jègai, buvo registruojamas specialios konstrukcijos elektroniniu signalo kaupikliu „Panasonic RR-US320“ (Japan). Signalas, užregistruotas duomenu ịvedimo ịrenginiu „Data Acquisition Card DAS1402" (Cyber Research, USA), buvo skaitmenizuojamas ir talpinamas personalinio kompiuterio atmintyje. Diskretizavimo dažnis buvo $1000 \mathrm{~Hz}$, o signalo skiriamoji geba - 12 bitų, arba 4096 lygiai. Traukio jègos signalo parametru analizè atlikta specialia programa, sukurta naudojant programavimo kalbą DELPHI.

2. 100 m nuotolio plaukimas laisvuoju stiliumi (s) siekiant geriausio rezultato.

3. Tirti rodikliai ịvertinti matematinès statistikos metodais: rezultatu skirtumo patikimumas pagal Mano-Vitnio-Vilkoksono kriterijaus $p$ reikšmes (Metha, Patel, 1996); skaičiavimai atlikti naudojant kompiuterinę programą Excel ir statistinių skaičiavimu programų paketu SPSS.

Tyrimo eiga. Po pramankštos (15 min tempimo pratimų) saleje buvo registruojama maksimalioji traukio jèga sausumoje ( $\mathrm{F} \max \mathrm{s}$ ). Po standartinès pramankštos baseine $(1000 \mathrm{~m}$ plaukimo vidutiniu intensyvumu) buvo fiksuojamas $100 \mathrm{~m}$ plaukimo laisvuoju stiliumi rezultatas. Paskui atliekami plaukimo su pririštu amortizatoriumi testai plaukiant vien rankomis, kojomis ir visiška koordinacija. Testų metu registruojamas traukio jègos signalas, pagal kuri ivertinami traukio jègos parametrai: jèga plaukiant rankomis (F vr); jèga plaukiant kojomis ( $\mathrm{F} \mathrm{vk}$ ); jèga plaukiant visiška koordinacija (F vpk). Po 5 minučiu aktyvaus poilsio tiriamieji atliko 30 sekundžiu plaukimo su pririštu amortizatoriumi testą, kurio metu buvo ívertinti traukio jègos parametrai: maksimalioji 30 sekundžių testo jèga (F max 30); jèga 30-ą sekundę (F 30 s) ir jègos svyravimų amplitudè (Svyr. ampl.).

\section{REZULTATAI}

Kompiuterinès dinamografinès sistemos programos lango pavyzdys pateiktas 1 paveiksle. Jame pavaizduoti užregistruotos jègos signalo 
pokyčiai per laiko vienetą, jo tendencijos kreivès, pagrindinès signalo komponentès, kiekybiniai iverčiai (rodikliai) ir tai, kaip jie atitinka tiriamuju treniruotumą. Traukio jèga, plaukiant su pririštu guminiu amortizatoriumi, pradžioje didèja įsitempiant amortizatoriui, stabilizuojasi ir pradeda mažèti, kai pasireiškia nuovargis. Signalą sudaro pagrindinè komponenté, rodanti bendrą jègos kitimo tendencija, ir svyravimai, nusakantys ranku ir koju grybšniu dinamines charakteristikas. Traukio jègos signalo analizè pradedama nuo pagrindinès komponentès išskyrimo. Norèdami išvengti registravimo metu esamo triukšmo ir atsižvelgdami i gana platų jègos svyravimų dažnio spektra, pagrindinei komponentei išskirti visą traukio jègos signalą sudalydavome 1 sekundès intervalais ir juose suskaičiuodavome medianines reikšmes. Pagrindinès komponentès signalo reikšmes (tiek pat reikšmių tais pačiais laiko momentais, kaip ir pradinio signalo metu) suskaičiuodavome, medianines reikšmes išdėstydavome dalijimo intervalu viduryje laiko atžvilgiu (1 pav. pažymèta „Žymès"), o tarp jų atlikdavome interpoliaciją kubiniu splainu. Šis masyvas ir yra pagrindinè jègos signalo komponentė (1 pav. pažymėta „Tendencija“), kurią atèmus iš pradinio signalo gaunamas jègos svyravimų signalas. Šių svyravimų amplitude buvo apibendrintai vertinama tuose pačiuose dalijimo intervaluose. Signalo atskaitymų absoliutaus dydžio reikšmès išrikiuojamos mažejjančia tvarka ir îverčiu laikoma 50-a iš eilès einanti reikšmè. Taip atmetamos atsitiktinès triukšmo ar registravimo artefaktų reikšmès. Dalijimo intervalai dažniausiai apima ne viena, o keletą plaukiko grybšnių, todèl šis 49-ių (didžiausių verčių) atskaitymu atmetimas signalo svyravimų amplitudei įvertinti didelès reikšmès neturi. Toliau, kaip ir pagrindinès jègos komponentès atveju, atliekama inter-

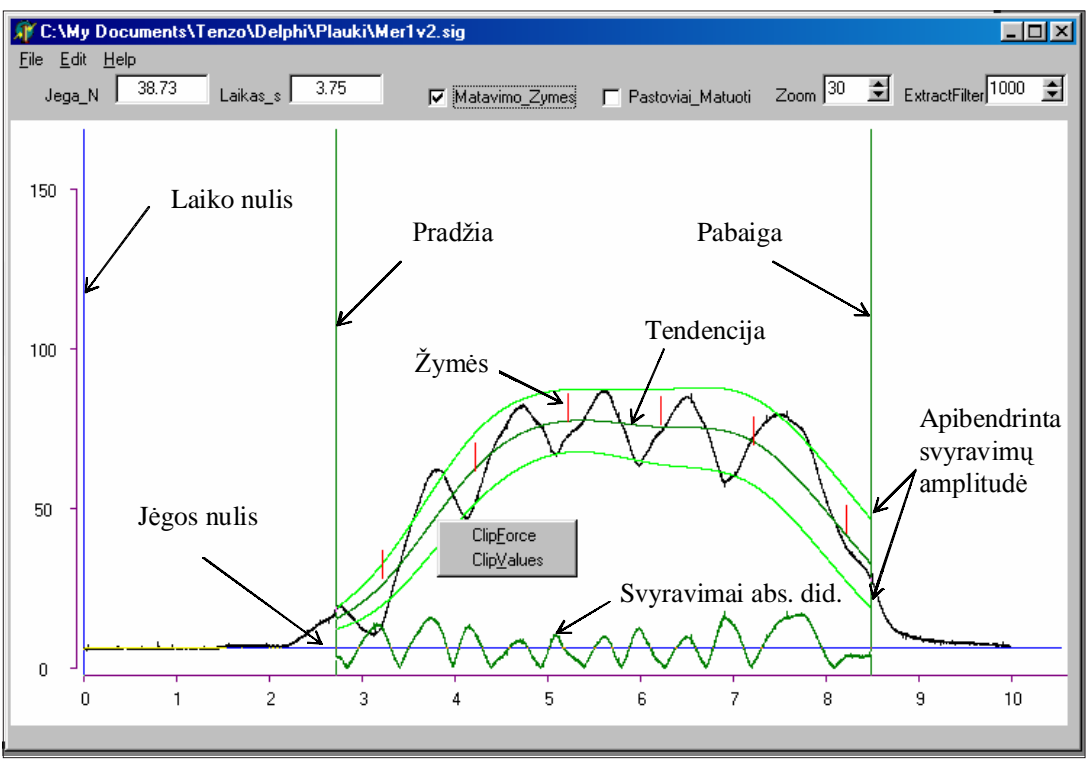

1 pav. Traukio jègos signalo analizès programos langas

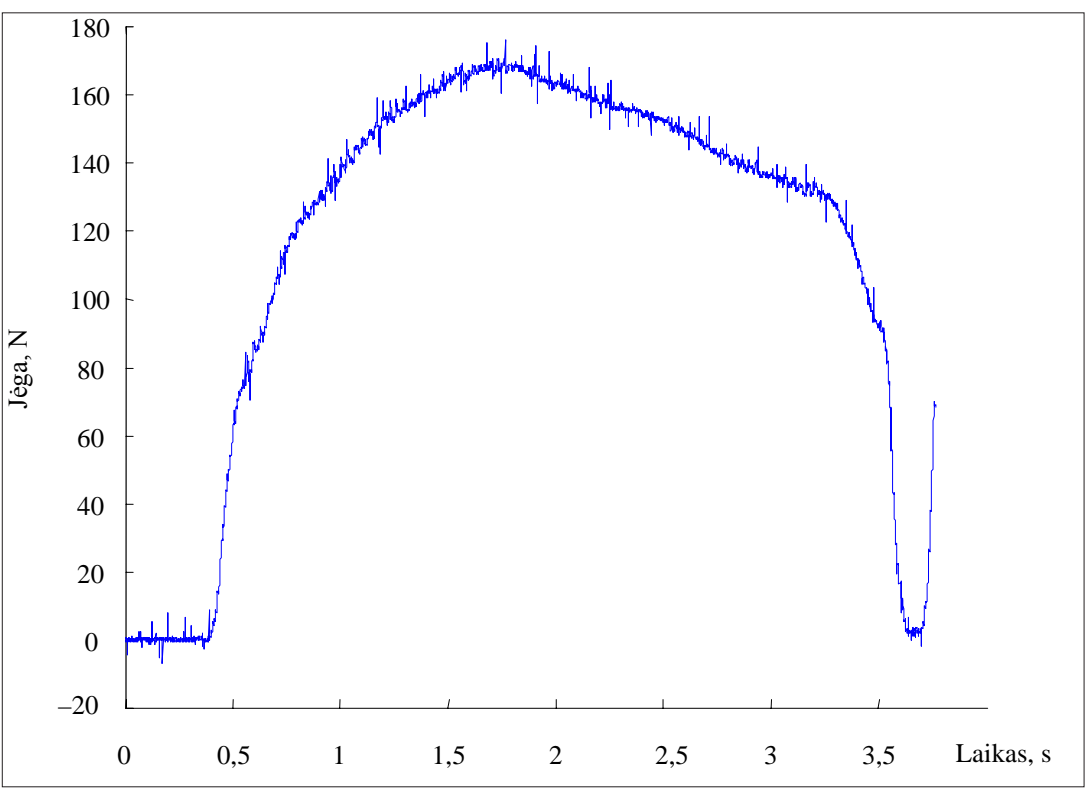

2 pav. Traukio jègos signalo pavyzdys, užregistruotas $30 \mathrm{~s}$ testo metu 
poliacija kubiniu splainu. Kad būtų vaizdžiau, 1 paveiksle šios reikšmès pavaizduotos dviem kreivẻmis, kurios apgaubia pradini signalą ir gaunamos pridejjus bei atėmus šias reikšmes iš pagrindinès signalo komponentès (,Apibendrinta svyravimų amplitude்“). Toks įverčio reikšmių vaizdavimas tyrimo metu padedavo kontroliuoti automatini šio parametro vertinimą. Tas rodiklis rodo tiriamojo masès centro svyravimus, vykstančius dèl dviejų pagrindiniu ji veikiančiu jègu (amortizatoriaus reakcijos jègos ir galūnių grybšnių sukuriamos traukio jègos) kintamos pusiausvyros. Ši plaukiko išugdomos traukio jègos svyravimu amplitudè priklauso nuo kūno masès, kuri tarp tiriamujų buvo gana tolygiai pasiskirsčiusi ir sieke 59-100 kg (t. y. skirtumas iki 40\%). Todèl norèdami įvertinti ir palyginti svyravimų amplitudę naudojome santykinę svyravimų amplitudę, kuri apskaičiuojama apibendrintą svyravimų amplitudę padalijus iš tiriamojo kūno masès.

2 paveiksle pateiktas traukio jègos signalo, atliekant 30-ies sekundžiu plaukimo testą, pavyzdys.

Ivairaus treniruotumo ir fizinio pajègumo plaukiku traukio jègos signalai 30 s testo metu pateikti 3 paveiksle. Šio paveikslo dešinèje, kaip kreivių žymès, pateikti 100 metrų plaukimo rezultatai sekundèmis. Matome, kad net keletas šio signalo parametru galètų būti naudojami treniruotumui ivvertinti. Atkreipiame dèmesic kad ne tik maksimalioji jejga, bet ir laiko momentas, per kuri ta jèga išugdoma, gali būti reikšmingas rodiklis. Taip pat traukio jègos reikšmè testo pabaigoje (30-ą sekundę) yra vienas iš svarbesniu jęgos ištvermès parametru (Платонов, 2000).

Traukio jègos signalo pagrindinę komponentę atėmus iš bendro signalo, išskiriama traukio jègos svyravimų signalo dedamoji, kuri parodo kiekvieno galūnès grybšnio sukuriamą traukio jègą. 4 paveiksle pavaizduotas išsamus šios signalo dedamosios fragmentas (4 pav. dešinejje) ir viso $30 \mathrm{~s}$ testo jègos svyravimu signalas su pažymèta fragmento vieta (4 pav. kairèje). Šio tipo signalų morfologinès analizès darbų rezultatai jau publikuoti mokslininkų darbuose (Платонов, 2000), tačiau ju registravimo metodai būdavo sunkiai pritaikomi praktikoje arba nevisiškai atitiko realius plaukiku judesius. Mūsų sukurta sistema leidžia išskirti
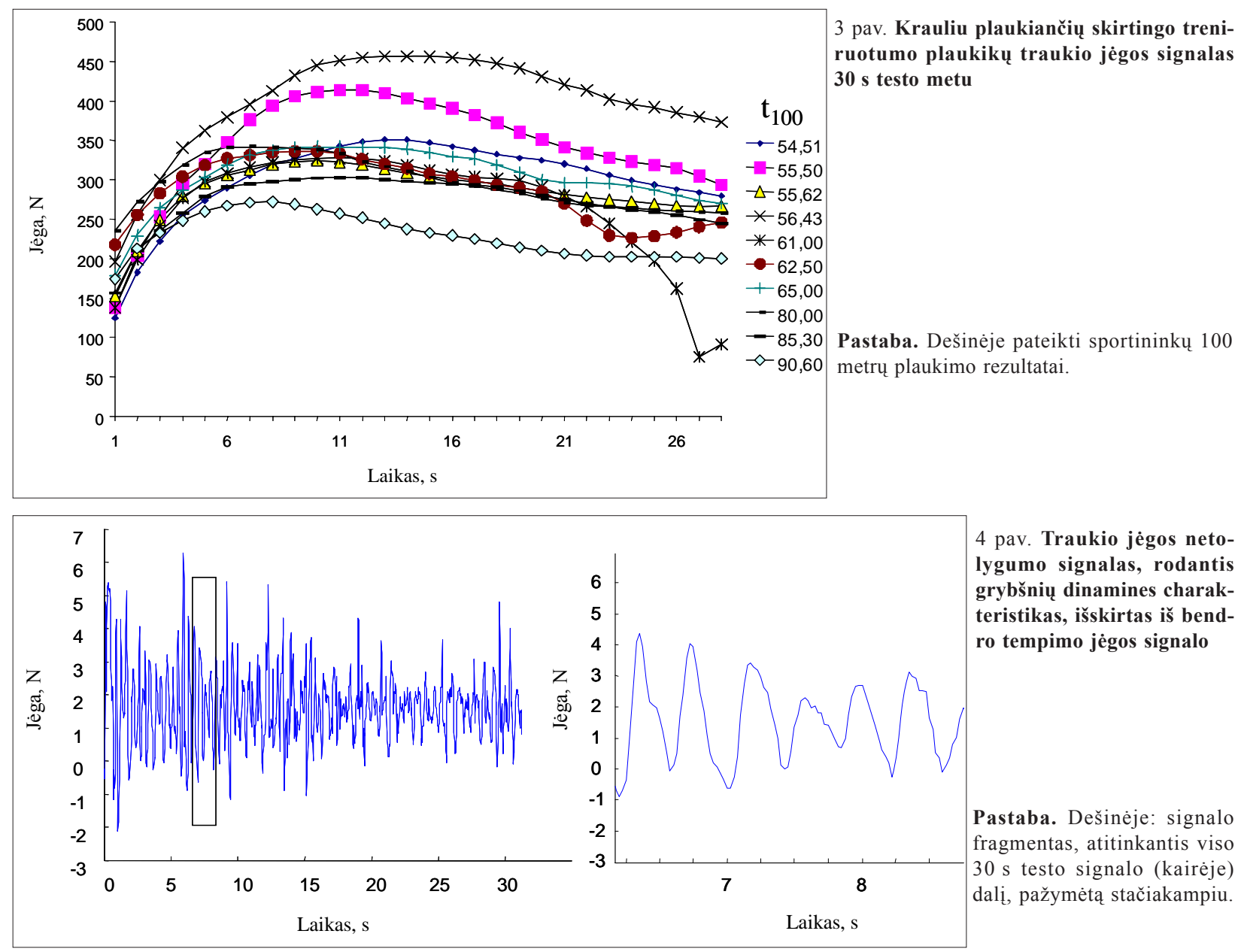


\begin{tabular}{|c|c|c|c|c|c|}
\hline Fmax s & F vpk & $\mathrm{F} \max 30$ & F $30 s$ & Svyr. ampl. & $\begin{array}{l}\text { Lentelè. Išmatuotų traukio jègos } \\
\text { ịverčių Mano-Vitnio-Vilkokso- }\end{array}$ \\
\hline 0,230 & 0,006 & 0,024 & 0,042 & 0,057 & no kriterijaus $p$ reikšmės \\
\hline
\end{tabular}

šiuos signalus iš plaukimo su pririštu amortizatoriumi užregistruoto traukio jẻgos signalo. Matome, kad šio išskirto signalo skiriamoji geba pakankama tolimesnei jo morfologijai analizuoti.

Pagal $100 \mathrm{~m}$ plaukimo rezultatus tiriamieji išsiskyre i d dvi grupes: treniruotus, kurių rezultatas viršijo I atskyrio normatyvą (57,0 s), ir mažesnio meistriškumo sportininkus. Kaip šias dvi grupes atskiria (klasifikuoja) išmatuoti ịverčiai, vertinome pagal Mano-Vitnio-Vilkoksono kriteriju (Metha, Patel, 1996). Šio kriterijaus $p$ reikšmès pateiktos lentelejej.

Nulinè hipotezè, teigianti, kad grupès nesiskiria, gali būti atmesta, jei $p$ reikšmès neviršija 0,05 . Šiuo atveju trys išmatuoti iverčiai pasirode tinkami (F vpk, F max 30, F 30 s), likusieji statistiškai nepatikimi. Tarp nepatikimų rodikliu atsidūrè ir daugelio autorių rekomenduojama maksimalioji traukio jèga sausumoje. Pastebèjome, kad svyravimų amplitudè mažeja didejjant sportininko treniruotumui ir jos, kaip sportininko treniruotumo įverčio, $p$ reikšmè artima statistiniam reikalavimui $(<0,05)$.

\section{REZULTATU APTARIMAS}

Vienas iš pagrindinių kiekybinių rodiklių, rodančiu plaukikų specialiosios jëgos lygi, yra traukio jèga - tai varomoji plaukiko jèga, nuo kurios dydžio reikšmingai priklauso plaukimo greitis ir rezultatas. Jègos realizacijos lygis plaukimo metu priklauso nuo sudetingo sąveikos mechanizmo tarp judejimą pirmyn sukuriančiu grybšniu judesių ir vandens terpès (Иссурин, 1988). Parenkant fizinio rengimo priemones, specialistai rekomenduoja vadovautis dinaminio atitikimo principu, t. y. jos turi atitikti varžybini pratimą pagal šiuos kriterijus: 1) judesio atlikimo raumenu grupes; 2) judesio amplitudę ir krypti; 3) judesio amplitudès akcentuojamają dalị; 4) pastangų dydị ir jų išugdymo laiką; 5) judesio greitị ir raumenų darbo režimą (Фомиченко, 2001).

Eksperimentiniai tyrimai, atlikti su įvairaus amžiaus plaukikais, rodo, kad specialiosios jègos, išugdomos plaukiant, dydis priklauso ne tik nuo plaukiko jègos ypatybiu, bet ir nuo plaukimo technikos tobulumo bei grybšniu judesių charak- teristikų (Bulgakova et al., 1990; Satkunskienè, Lagūnavičienè, 2000).

Suprasdami specialiosios jègos reikšmingumą ugdant plaukikus, ieškojome metodų, kurie leistų registruoti, išsamiau tyrinèti ir analizuoti plaukiku išugdomos traukio jègos rodiklių pokyčius per laiko vienetą specifinejje vandens aplinkoje, nes tyrimais patvirtinta, kad plaukikų rezultatus geriausia prognozuoti remiantis baseine atliktų testų ir matavimų rezultatais (Skyrius ir kt., 2004).

Naudodami kompiuterizuotą dinamogarafinę sistemą ir analizuodami įvairaus meistriškumo plaukikų sukuriamos traukio jègos signalus vandenyje, pastebejjome siūlomos metodikos pranašumą prieš dažnai plaukikų testavimo praktikoje taikomą dinamometrijos metodą, kuriuo nustatomos tik maksimaliosios arba vidutinès traukio jègos reikšmès. Tai, kad mūsų siūlomas jẻgos ¿vertis plaukiant vandenyje visiška koordinacija yra vienas iš stabiliausių rodiklių ir gali būti patikimai naudojamas rezultatams prognozuoti, pastebejjo ir kiti tyrejjai (Lagūnavičienè, Skyrienè, 1989; Кашкин и др., 1995). Analizuojant signalus siūlomu metodu, galima nustatyti ne tik absoliučias tiriamu parametrų reikšmes, bet ir matyti jègos kitimą plaukiant viso testo metu. Statistiškai patikimais gali būti laikomi net keli mūsu ịvertinti kriterijai. Tai rodo, kad sportininko rezultatui prognozuoti reikètų naudoti šiu kriterijų derinius. Svarbu ir tai, kad dinamografine sistema leidžia išskirti sukuriamos traukio jègos netolygumą ciklo ir net grybšnio metu. Apibendrintas jègos svyravimų rodiklis gali papildyti siūlomus patikimus rodiklius (F vpk, F max 30, F 30 s), ne tik įvertinti specialuji fizini parengtuma, bet ir parodyti sportininko technini meistriškumą. Tirtų plaukikų išugdomos traukio jègos kitimo per laiko vieneta analizė patvirtina ir kitų tyrèjų nuomonę, kad siekiant maksimalaus plaukimo rezultato tikslinga plaukimo techniką tobulinti taip, kad traukio jègos svyravimai ciklo metu būtų kiek galima mažesni, t. y. siekti tolygaus plaukimo (Sidney et al., 1996; Dobsaj et al., 2003).

\section{IŠVADOS}

1. Plaukikų specialiosios jègos registravimas ir analizė naudojant kompiuterizuotą dinamogra- 
finę sistemą leidžia fiksuoti ne tik absoliučius traukio jègos dydžius, kurie teikia svarbią informaciją apie sportininko techninio parengtumo lygi, bet ir sukuriamos traukio jejgos svyravimu netolygumus plaukimo ciklo ir net grybšnio metu.

2. Tiriant plaukikų specialuji fizini parengtumą kompiuterizuota dinamografine sistema nustatyta, kad plaukikų testavimo metu dažnai naudojamas maksimaliosios traukio jègos sausumoje rodiklis $100 \mathrm{~m}$ plaukimo laisvuoju stiliumi rezultatams prognozuoti pasirodè nepakankamai tinkamas. Geriausiai rezultatus parodo šie plaukimo testo su pririštu amortizatoriumi išugdomos traukio jègos rodikliai: traukio jèga plaukiant visiška koordinacija (F vpk), maksimalioji 30 sekundžių testo jèga (F max 30), jèga 30-ą sekundę (F $30 \mathrm{~s}$ ).

\section{LITERATŪRA}

Bing, X. (1989). The effects of aquatic isokinetic on arm pulls in breaststroke swimming. Sports Science, 11 (1), $29-33$.

Bulgakova, N. Z., Vorntsov, A. R., Fomichenko, T. G. (1990). Improving the technical preparedness of young swimmers by using strength training. Soviet Sport Review, $102-104$.

Costill, D. L., King, D. S., Tomas, R. T., Hargreaves, M. (1994). Effects of reduced training on muscular power in swimmers. Physician and Sports Medicine, 13 (2), 100101.

Counsilmen, J. E., Counsilmen, B. E. (1994). The new science of swimming. Prentice Hall.

Curran, C. T. (1980). Isometric, isotonic and isokinetic training programmes and swimming performances. International Swimmer, 17 (6), 11-12.

Dopsaj, M., Matkovic, I., Thanopoulos, V., Okicic, T. (2003). Reliability and validity of basic kinematics and mechanical characteristics of pulling force in swimmers measured by the method of tethered swimming with maximum intensity of 60 seconds. Facta Universitatis, Series. Physical Education and Sport, 1 (10), 11-22.

Dopsaj, M., Matkovic, I., Zdravkovic, I. (2000). The relationship between $50 \mathrm{~m}$ - freestyle results and characteristics of tethered forces in male sprint swimmers: A new approach to tethered swimming test. Facta Universitatis, Series. Physical Education and Sport, 1 (7), $15-22$.

Hopper, R. T., Hadley, C., Piva, M., Bambauer, B. (1983). Measurements of power delivered to an external weight. Biomechanics and Medicine in Swimming. Champaign, IL: Human Kinetics Publishers. P. 113-119.

Ikuta, Y., Wakayoshi, K. \& Nomura, T. (1996). Determination and validity of critical swimming force as performance index in tethered swimming. In J. P. Troup, A. P. Hollander, D. Stresse, S. W. Trappe, J. M. Cappaert, \& T. A. Trappe (Eds.), Biomechanics and Medicine in Swimming VII (pp. 146-151). London: Chapman \& Hall. Juozaitis, J. A., Radžiukynas, D., Statulevičius, V. (1998). 14-15 metų plaukikų kojų raumenų jègos, greičio jègos ir plaukimo rezultatų ryšys. Sporto mokslas, 1 (10), $22-$ 25.

Lagūnavičienè, N., Skyrienè, V. (1989). Jaunuju plaukiku perspektyvumo nustatymas remiantis specialios jegos rodikliais: metodines rekomendacijos. Vilnius: Respublikinis sporto metodikos kabinetas.

Metha, C. R., Patel, N. R. (1996). SPSS Exact Tests 7,0 for Windows. ISBN 1-56827-108-5. Chicago.
Satkunskienè, D., Lagūnavičienè, N. (2000). Traukos jègos plaukiant krauliu ivertinimas. Ugdymas. Kūno kultūra. Sportas, 1 (34), 35-41.

Sidney, M., Pelayo, P. \& Robert, A. (1996). Tethered forces in crawl stroke and their relationship to anthropometrics characteristics and sprint swimming performance. Journal of Human Movement Studies, 31, $1-12$.

Skyrius, E., Zuozienė, I. J., Poderys, J., Lagūnavičienė, N. (2004). Praktiniai tyrimai ir laboratoriniai plaukiku parengtumo vertinimai. Sporto mokslas, 1 (35), 48-51.

Sokolovas, G., Lagūnavičienė, N., Mažutaitis, Š. (1999). Plaukikų jègos greitumo rodiklių analizè. Sporto mokslas, 1 (15), 35-40.

Yeater, R., Martin, B., White, M-K. \& Gilson, K. (1981). Tethered swimming forces in the crawl, breast and back strokes and their competitive performance. Journal of Biomechanics, 14 (8), 527-537.

Абсалямов, Т., Тимакова, Т. (1983). Научное обеспечение подготовки пловияов. Москва: ФиС.

Гордон, С. М., Сируц, А. Л. (1990). Силовая подготовка юньхх пловцов на этапах годичного цикла. Минск: Физкультура и спорт.

Иссурин, В. Б. (1988). Формирование спортивнотехнического мастерсва в водных видах спорта: дис. докт. пед. наук. Москва.

Кашкин, А. А., Морозов, С. Н., Попов, О. И. (1995). Оиенка силовых способностей юных пловцуов. Москва: РГАФК.

Оноприенко, Б., Атаманов, В. (1973). Тензиометрия в плавании. Теория и практика физической культуры, 8, $66-69$.

Платонов, В. Н. (2000). Плавание. Киев: Олимпийская литература.

Ратов, И. П. (1994). Двигательные возможности человека (нетрадиционные методы их развития и восстановления). Минск: Физкультура и спорт.

Рудокене, Н. М. (1981). Эффективные методы специиальной силовой подготовки юных пловцов: дис. канд. пед. наук. Москва.

Скирюс, Э. (1986). Силовая выносливость пловца и методы её совершенствования с применением тренажёрных устройств на суше: дис. канд. пед. наук. Москва.

Фомиченко, Т. Г. (2001). Совершенствование силовой и технической подготовленности пловцов различных возрастных групn. Москва: СпортАкадемПресс. 


\title{
COMPUTER-BASED DYNAMOGRAPHIC SYSTEM FOR ANALYSIS OF SWIMMERS' PULLING FORCE PARAMETERS
}

\author{
Ilona Judita Zuozienè ${ }^{1}$, Algimantas Kriščiukaitis², Kazimieras Muckus ${ }^{1}$ \\ Lithuanian Academy of Physical Education ${ }^{I}$, Institute for Biomedical Research of Kaunas University of \\ Medicine $^{2}$, Kaunas, Lithuania
}

\begin{abstract}
The aim of this work was to develop the method for registration and processing the pulling force signal of a swimmer performing regular tasks in water.

Materials and methods: 24 volunteer swimmers performed the groups of tests: a) a test of the maximal static force produced by shoulder muscles imitating swimming movements, pulling force in tethered swimming; b) only hands movements; c) only feet movements; d) fully coordinated swimming movements (using both hands and feet); e) a swimming test with the duration of $30 \mathrm{~s}$ at maximum force. Pulling force signal was registered using the dynamometer and stored using a special design portable analog signal storage device. The signal storage device has a special water resistant design and battery power supply for usage in close distance to the water. The analog pulling force signal from the storage device was digitized and transferred into computer memory using Data Acquisition Card DAS1402 (Cyber Research, USA). Digitization sampling frequency was $1000 \mathrm{~Hz}$ and resolution -12 bits. A special program was devised to evaluate various parameters of traction signal. Interactive control of the program allows the investigator to measure instantaneous force values during the whole test signal. The maximal force potential produced by shoulder muscles imitating swimming movements was estimated in this way. Pulling force signal registered in the water reflects alterations related with every single movement performed by the swimmer. For special signal processing the algorithm was worked out to determine and evaluate the trend line of force and short term alterations. As reference estimate for all parameters we used the time result of $100 \mathrm{~m}$ swimming during the test competitions.

Conclusions: 1) Usage of special derived parameters of swimmers' pulling force signal, obtained using special signal processing methods together with conventional force estimates, could significantly improve the training process; 2) the usually used maximal static force test showed comparatively poor correlation with time result of $100 \mathrm{~m}$ swimming. As the best parameters reflecting swimmers' condition we recommend the ones obtained during the test of tethered swimming: force of full coordinated swimming, maximal force of 30 -second test, force of the 30-th second.
\end{abstract}

Keywords: swimming, pulling force, dynamographic system.

Gauta 2004 m. gruodžio $30 \mathrm{~d}$.

Received on December 30, 2004

Ilona Judita Zuozienè

Lietuvos kūno kultūros akademija

(Lithuanian Academy of Physical Education)

Sporto g. 6, LT-44221 Kaunas

Lietuva (Lithuania)

Tel +370 37302666

E-maili.zuoziene@lkka.1t 